Vol.61: e18160694, 2018

http://dx.doi.org/10.1590/1678-4324-2018160694

ISSN 1678-4324 Online Edition
BRAZILIAN ARCHIVES OF

BIOLOGY AND TECHNOLOGY

AN INTERNATIONAL JOURNAL

\title{
Combining a probiotic with organic salts presents synergistic in vitro inhibition against aquaculture bacterial pathogens
}

\author{
Norha Constanza Bolivar ${ }^{1 *}$, Esmeralda Chamorro Legarda ${ }^{1}$, Walter Quadros Seiffert ${ }^{1}$, \\ Edemar Roberto Andreatta ${ }^{1}$, Felipe do Nascimento Vieira ${ }^{1}$ \\ ${ }^{1}$ Universidade Federal de Santa Catarina - Aquicultura Laboratorio de Camarões Marinhos, Florianópolis, Santa \\ Catarina, Brasil
}

\begin{abstract}
This study aimed to evaluate 1) the in vitro effect of organic salts on the growth of the probiotic Lactobacillus plantarum and then 2) the combined use of a probiotic with organic salts on the in vitro inhibition of V. alginolyticus, A. hydrophila, E. coli, P. aeruginosa, and S. agalactiae. In vitro tests were performed with eight different organic salts, including butyrate, propionate, succinate, citrate, formate, fumarate, glutamate, and acetate, at two pH values (6.2 and 7.1) to determine their effect on the growth kinetics of L. plantarum. In addition, each organic salt was tested alone and in combination with L. plantarum to evaluate the inhibitory effect against the pathogenic bacteria noted above in either condition. Sodium citrate and formate inhibited the growth of L. plantarum, but sodium glutamate, succinate and fumarate stimulated it. Sodium propionate, butyrate, and acetate did not affect probiotic growth at all. Inhibition against all pathogens was significantly higher in the presence of the probiotic and lower $\mathrm{pH}$. Comparing all organic salts at the two $\mathrm{pH}$ values, butyrate, acetate, and propionate exhibited more inhibition against $\mathrm{V}$. alginolyticus than the others, while propionate had higher inhibition against A. hydrophila, E. coli, P. aeruginosa, and fumarate successfully inhibited S. agalactiae. Based on these results, it can be concluded that organic salts showed better in vitro inhibition against the aquaculture pathogenic bacteria tested when combined with the probiotic L. plantarum.
\end{abstract}

Keywords: Lactobacillus plantarum, sodium butyrate, sodium propionate, aquaculture pathogenic bacteria.

*Author for correspondence: norhabolivar@yahoo.com 


\section{INTRODUCTION}

World aquaculture production has grown progressively in recent decades. It increased at an annual average rate of $3.2 \%$ and reached 97.2 million tons in $2013{ }^{1}$. For the first time, aquaculture production has surpassed capture (93.7 million tons). However, factors such as intensive production systems, water pollution, as well as ecological and nutritional imbalance, have led to the emergence of several diseases in aquaculture production (Lightner 2011). According to the FAO (Food and Agriculture Organization $)^{2}$, aquaculture production has been affected by the emergence of several diseases, particularly those caused by viruses and bacteria, leading to significant losses in farmed fish, shrimp, mollusks, and echinoderms. For example, in 2012, Early Mortality Syndrome (EMS), which is caused by a Vibrio parahaemolyticus strain, led to reduced shrimp production volumes in some Asian and Latin American countries, with more significant reductions in $2013^{3,4}$. The negative effects of bacterial infection include anorexia, inactivity, low growth rate, muscle necrosis, and, consequently, high mortality 5. Additionally, several bacterial diseases caused by Aeromonas sp., Pseudomonas sp. and Streptococcus sp. have being related as cause of high mortality in fish farming ${ }^{6}$.

Antibiotics are typically used to control bacterial diseases. Although some of these products may reduce mortality rates, their inappropriate or excessive use in aquaculture has led to the emergence of resistant bacteria ${ }^{7}$. In addition, the possible impact of chemical residues on human health and the environment is a concern ${ }^{8}$, prompting the European Union to ban the use of antibiotics in animal production. Since this has been a global trend, alternatives to antibiotics in animal production have been tested all over the world, such as probiotics and, more recently, organic salts.

Probiotics can inhibit pathogenic bacteria and stimulate the host's immune system without leaving toxic residues in animal products ${ }^{9,10}$. Among probiotic bacteria used in aquaculture, lactic acid bacteria predominate based on rapid reproduction, production of antimicrobial compounds, including bacteriocins, hydrogen peroxide, organic acids, and lactic acid, and stimulation of nonspecific immune response of the host ${ }^{9}$.

On the other hand, organic acids efficiently inhibit pathogenic bacteria, particularly Gram-negative bacteria, by reducing the $\mathrm{pH}$ of their environment. Organic acids disrupt the cell wall, causing the release of protons from the cytoplasm, thereby creating an imbalance in cell $\mathrm{pH}$ and, hence, causing bacterial death. Therefore, organic salts have been evaluated as a possible replacement for antibiotics with the aim of improving animal performance and health ${ }^{11}$. Many organic acids are available in form of salts, such as sodium, potassium, and calcium. These salts are less corrosive and present better solubility in water when compared to their acid counterparts ${ }^{12}$. In addition to reducing intracellular $\mathrm{pH}$, organic salts are able to form chelating complexes with trace minerals, rendering them unavailable and limiting the growth of other microorganisms ${ }^{13}$. The potential of some organic salts to inhibit different pathogenic bacteria species has been demonstrated ${ }^{14}$.

It was therefore hypothesized that the chelating compounds formed by organic salts combined with the probiotic effects promoted by lactic acid bacteria would, by their synergism, inhibit the growth of pathogenic bacteria, thereby preventing the spread of disease. Diseases are considered as one of the main problem that the aquaculture industry faces today. Consequently, the demand for additives that improve the performance and the resistance of the aquatic organisms against different diseases is increasing. The use of probiotics along with organic salts, such as additives for prevention of pathogens, can be a very useful tool to be considered for aquaculture thus avoiding the unnecessary use of antibiotics and consequently generating a positive impact in the productive sector. Since few studies on the combined use of 
probiotics and organic salts have been reported ${ }^{15}, 16$; this study aimed to evaluate 1) the in vitro effect of organic salts on the growth of the probiotic Lactobacillus plantarum and then 2) the combined use of organic salts and probiotics on the in vitro inhibition of V. alginolyticus, A. hydrophila, E. coli, P. aeruginosa, and S. agalactiae.

\section{MATERIALS AND METHODS}

The experiment was performed at the Laboratório de Camarões Marinhos (LCM) of the Universidade Federal de Santa Catarina (UFSC), Brazil.

\section{Biological material and organic salts}

The bacterial strain used as a probiotic was $L$. plantarum, which was isolated from $L$. vannamei adults ${ }^{17}$ and was maintained in the collection of microorganisms of the microbiology sector of LCM/UFSC.

Eight different organic salts were evaluated: sodium butyrate $\left(\mathrm{C}_{3} \mathrm{H}_{7} \mathrm{COONa}\right)$, sodium propionate $\left(\mathrm{C}_{3} \mathrm{H}_{5} \mathrm{NaO}_{2}\right)$, sodium acetate $\left(\mathrm{C}_{2} \mathrm{H}_{3} \mathrm{NaO}_{2}\right)$, sodium citrate $\left(\mathrm{Na}_{3} \mathrm{C}_{6} \mathrm{H}_{5} \mathrm{O}_{7}\right)$, sodium glutamate $\left(\mathrm{C}_{5} \mathrm{H}_{8} \mathrm{NO}_{4} \mathrm{Na}\right)$, sodium succinate $\left(\mathrm{C}_{4} \mathrm{H}_{4} \mathrm{Na}_{2} \mathrm{O}_{4}\right)$, sodium fumarate $\left(\mathrm{C}_{4} \mathrm{H}_{2} \mathrm{Na}_{2} \mathrm{O}_{4}\right)$, and sodium formate (HCOONa). Five different pathogenic bacteria were tested: Vibrio alginolyticus BCCM 2068, Aeromonas hydrophila (CPQBA 22808 DRM), Escherichia coli ATCC 25102, Pseudomonas aeruginosa ATCC 0053 and Streptococcus agalactiae (GRS 2035 isolated strain of Nile Tilapia).

\section{In vitro effect of organic salts on the growth of the probiotic bacterium $L$. plantarum}

Each organic salt was diluted at 5\% in tubes containing MRS (Man, Rogosa, \& Sharpe) broth as culture medium. The $\mathrm{pH}$ of the organic salts was adjusted to two different values that simulated shrimp diet $\mathrm{pH}(6.2)$ and the intestinal $\mathrm{pH}$ of $L$. vannamei (7.1), according to the method described by Silva et al. (2013). The probiotic bacterium $L$. plantarum with 24 hours of growth was inoculated into each

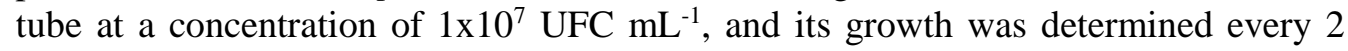
hours using a microplate reader (ASYS, Expert Plus) at an optical density (OD) of 630 $\mathrm{nm}$. The probiotic growth kinetics in 24 hours was determined, and the maximum growth rate $(\mu \max )(\mathrm{Eq} .1)$, cell-doubling time (td) (Eq. 2), and final bacterial count were calculated. The concentration of the probiotic was determined as a function of the previously determined growth curve and is expressed in CFU ml ${ }^{-1}$ (colony-forming units per milliliter). The control samples consisted of tubes containing only MRS broth adjusted for the two $\mathrm{pH}$ values and with no addition of organic salts. The initial concentration obtained for each salt is presented in Table 1.

Maximum growth rate:

$\mu_{\text {max }}=\frac{\ln (z)-\ln (Z 0)}{d t} \quad$ Equation 1

where $\mu \max =$ maximum growth rate, $\mathrm{Z}=$ concentration $\left(\mathrm{CFUml}{ }^{-1}\right), \mathrm{Z} 0=$ initial concentration of the inoculum $\left(\mathrm{CFUml}^{-1}\right)$, and $\mathrm{dt}=$ culture time (hours).

Cell-doubling time:

$t_{d}=\frac{\ln (2)}{\mu_{\max }}$

Equation 2 
Table 1. Millimolar concentration (mM) of each organic salt diluted at 5\% MRS broth.

\begin{tabular}{ll}
\hline Organic salt & Concentration $(\mathbf{m M})$ \\
\hline Sodium butyrate & 454 \\
Sodium propionate & 520 \\
Sodium acetate & 609 \\
Sodium citrate & 193 \\
Sodium glutamate & 267 \\
Sodium succinate & 357 \\
Sodium fumarate & 312 \\
Sodium formate & 735 \\
\hline
\end{tabular}

In vitro effect of organic salts and the probiotic bacterium on different pathogenic bacteria

The in vitro inhibitory effect of L. plantarum and each organic salt ( $\mathrm{pH} 6.2$ and 7.1) against $V$. alginolyticus, A hidrophyla, E coli, $P$ aeruginosa and $S$. agalactiae were then tested individually and in combination (probiotic + organic salt) and evaluated by minimum inhibitory concentration (MIC) assays using a microplate reader.

For individual testing of organic salts, $100 \mu \mathrm{L} \mathrm{PB}$ (Poor Broth, containing 1\% peptone and $0.5 \% \mathrm{NaCl}, \mathrm{pH} 7.4$ ) were added to each well of a 96-well flat bottom microplate. A $100 \mu \mathrm{L}$ volume of each organic salt was added to the first well and then serially diluted by a factor of $1: 2$ to the $12^{\text {th }}$ well. Finally, $20 \mu \mathrm{L}$ of each pathogenic bacterium (previously maintained in $\mathrm{PB}$ at $28^{\circ} \mathrm{C}$ for 8 hours) were added to each well at a concentration adjusted to $1 \times 10^{3} \mathrm{CFU} \mathrm{mL}^{-1}$, according to the previously determined growth curve. The tests were performed for each pathogenic bacterium in triplicate. For probiotic testing, the supernatant of the bacterium was used in MIC analysis (in order to the cells do not interfere in the absorbance). For this, L. plantarum was inoculated in MRS broth, incubated at $36^{\circ} \mathrm{C}$ for 24 hours, and then centrifuged for 30 minutes at $4000 \times \mathrm{g}$. The supernatant was filtered through a $0.22-\mu \mathrm{m}$ membrane. Subsequently, a solution containing $50 \mu \mathrm{L}$ of the supernatant plus $50 \mu \mathrm{L}$ of organic salt (at 5\%, diluted in PB) was added to the first well of the microplate and serially diluted by a factor of 2 up to the $12^{\text {th }}$ well. A $100 \mu \mathrm{L}$ volume of PB had previously been added to all microplate wells. Afterwards, $20 \mu \mathrm{L}$ of the pathogenic bacterium at a concentration of $1 \times 10^{3} \mathrm{CFUmL}^{-1}$ were added to each well. Tests were carried out for each pathogenic bacterium in triplicate. For the controls with no probiotic, only PB and individual organic salts were used, and the pathogenic bacterium was added or not (positive and negative controls, respectively). Poor broth containing individual organic salts and the supernatant were used as controls, and the pathogen was added or not (positive and negative controls, respectively). Microplates were incubated at $35^{\circ} \mathrm{C}$ for 12 hours, and microorganism growth was determined using a microplate reader at $630 \mathrm{~nm}$ OD. The concentration was obtained according to the previously determined growth curve of each pathogenic bacterium.

\section{Statistical analyses}

Normality was evaluated by Shapiro-Wilk test. Microbial kinetics values (celldoubling time, maximum growth rate, and concentration) and minimum inhibitory concentration were $\log (\mathrm{x}+1)$ transformed for data normalization and variance homogenization. Homoscedasticity was evaluated by the test of Bartlett. Microbial kinetics and minimum inhibitory concentration data were submitted to factorial analysis of variance $(\alpha<0.05)$. When significant differences were detected, means were compared by the HSD (honest significant difference) test of Tukey ${ }^{18}$. 


\section{RESULTS}

\section{In vitro effect of organic salts on the growth of the probiotic bacterium $L$. plantarum}

Microbial growth kinetics (Figure 1) shows that sodium citrate and formate, at both pH 6.2 and 7.1, significantly inhibited the growth of L. plantarum. On the other hand, sodium succinate, fumarate, and glutamate stimulated $L$. plantarum growth, which reached higher concentrations during the growth curve compared with the control (probiotic bacterium with no addition of organic salts). Sodium butyrate, propionate and acetate had no effect on the growth of L. plantarum.

$\mathbf{A}$

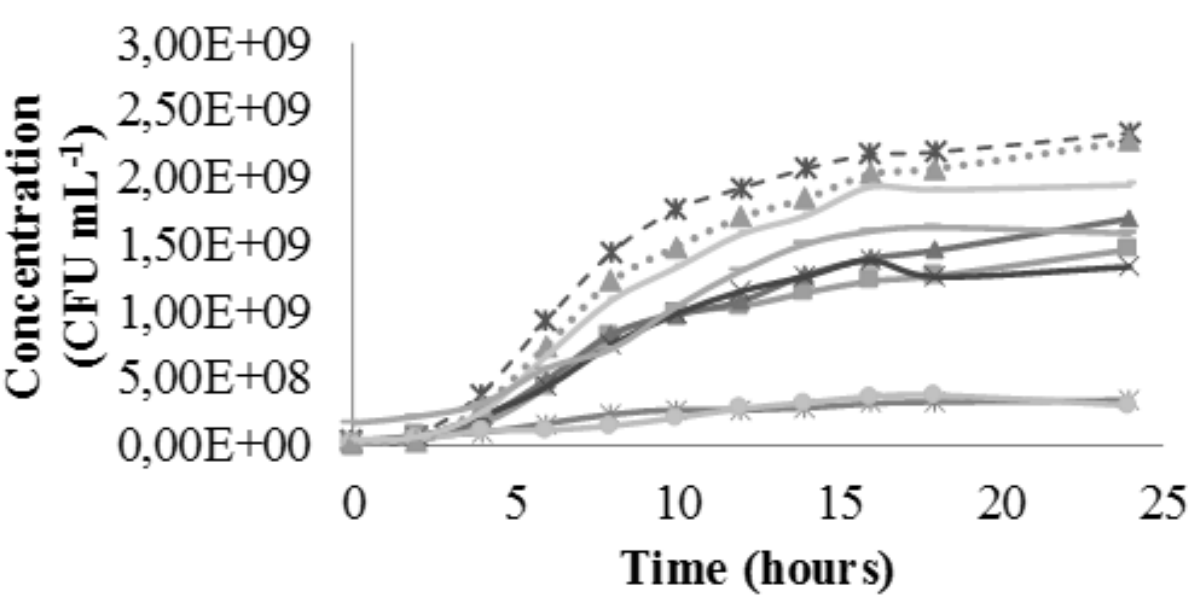

B

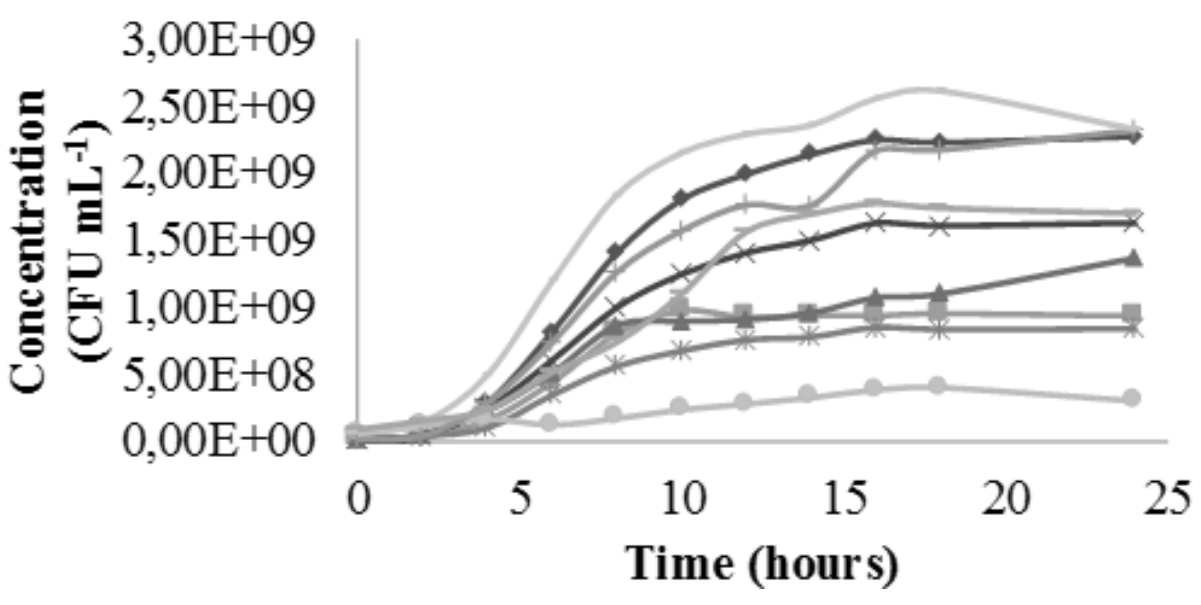

Figure 1. Growth kinetics of Lactobacillus plantarum during 24 hours, as expressed in colony-forming units (CFU $\mathrm{ml}^{-1}$ ), with the addition of organic salts at $\mathrm{pH} 6.2$ (A) and $\mathrm{pH} 7.1(\mathrm{~B})$. Organic salts: Glutamate ( $\left.-*\right)$, acetate (

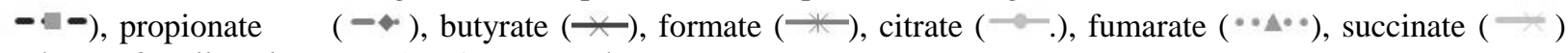
and Lactobacillus plantarum $(\longrightarrow)$ as control.

Maximum growth rate, cell-doubling time, and concentration were calculated based on data obtained after 12 hours of growth, which was the average time of all treatments before the stationary phase started. Probiotic growth rates and concentrations were significantly lower upon addition of sodium citrate and sodium formate in a $\mathrm{pH}$ independent manner; consequently, cell-doubling time increased when these salts were added relative to control treatment (Table 2). The other organic salts had no effect on L. plantarum growth, as shown by the lack of significant differences in growth rate, 
cell-doubling time, and concentration compared with the control treatment, as measured at 12 hours.

Table 2 Lactobacillus plantarum concentration, maximum growth rate, and cell-doubling time when incubated with different organic salts at two $\mathrm{pH}$ values.

\begin{tabular}{|c|c|c|c|}
\hline \multicolumn{4}{|l|}{ pH 6.2} \\
\hline & $\mathrm{C}\left(\mathrm{CFU} \mathrm{ml} \mathrm{m}^{-1} \times 1^{8}\right)$ & $\mu \max$ & td \\
\hline Glutamate & $21.16 \pm 0.96^{c}$ & $0.34 \pm 0.00^{\mathrm{c}}$ & $2.06 \pm 0.02^{\mathrm{a}}$ \\
\hline Acetate & $12.36 \pm 0.64^{c}$ & $0.29 \pm 0.00^{c}$ & $2.37 \pm 0.04^{\mathrm{a}}$ \\
\hline Propionate & $12.76 \pm 0.56^{\mathrm{c}}$ & $0.30 \pm 0.00^{\mathrm{c}}$ & $2.35 \pm 0.03^{\mathrm{a}}$ \\
\hline Butyrate & $13.49 \pm 0.62^{\mathrm{c}}$ & $0.30 \pm 0.00^{\mathrm{c}}$ & $2.31 \pm 0.03^{\mathrm{a}}$ \\
\hline Formiate & $4.61 \pm 0.25^{\mathrm{a}}$ & $0.21 \pm 0.00^{\mathrm{a}}$ & $3.30 \pm 0.07^{c}$ \\
\hline Citrate & $4.68 \pm 0.05^{\mathrm{a}}$ & $0.21 \pm 0.00^{\mathrm{a}}$ & $3.28 \pm 0.01^{\mathrm{c}}$ \\
\hline Fumarate & $19.01 \pm 0.48^{\mathrm{c}}$ & $0.33 \pm 0.00^{c}$ & $2.11 \pm 0.01^{\mathrm{a}}$ \\
\hline Succinate & $17.79 \pm 0.79^{c}$ & $0.32 \pm 0.00^{\mathrm{c}}$ & $2.15 \pm 0.02^{\mathrm{a}}$ \\
\hline Control & $14.99 \pm 0.87^{\mathrm{c}}$ & $0.31 \pm 0.00^{c}$ & $2,25 \pm 0.01^{\mathrm{a}}$ \\
\hline$p$-value & $<0.001$ & $<0.001$ & $<0.001$ \\
\hline \multicolumn{4}{|l|}{ pH 7.1} \\
\hline & $\mathrm{C}\left(\mathrm{CFU} \mathrm{ml} \mathrm{ml}^{-1} \times 1^{8}\right)$ & $\mu \max$ & td \\
\hline Glutamate & $21.94 \pm 0.68^{c}$ & $0.34 \pm 0.00^{c}$ & $2.04 \pm 0.02^{\mathrm{a}}$ \\
\hline Acetate & $11.24 \pm 0.47^{\mathrm{c}}$ & $0.28 \pm 0.00^{\mathrm{b}}$ & $2.44 \pm 0.03^{\mathrm{a}}$ \\
\hline Propionate & $11.01 \pm 0.54^{\mathrm{c}}$ & $0.28 \pm 0.00^{\mathrm{b}}$ & $2.45 \pm 0.04^{\mathrm{a}}$ \\
\hline Butyrate & $15.96 \pm 0.76^{\mathrm{c}}$ & $0.31 \pm 0.00^{\mathrm{c}}$ & $2.21 \pm 0.03^{\mathrm{a}}$ \\
\hline Formiate & $9.51 \pm 0.35^{\mathrm{b}}$ & $0.27 \pm 0.00^{\mathrm{b}}$ & $2.56 \pm 0.03^{b}$ \\
\hline Citrate & $4.77 \pm 0.27^{\mathrm{a}}$ & $0.21 \pm 0.00^{\mathrm{a}}$ & $3.26 \pm 0.07^{\mathrm{c}}$ \\
\hline Fumarate & $19.57 \pm 0.45^{\mathrm{c}}$ & $0.33 \pm 0.00^{\mathrm{c}}$ & $2.10 \pm 0.01^{\mathrm{a}}$ \\
\hline Succinate & $24.86 \pm 0.88^{c}$ & $0.35 \pm 0.00^{\mathrm{c}}$ & $1.98 \pm 0.02^{\mathrm{a}}$ \\
\hline Control & $17.65 \pm 0.78^{\mathrm{c}}$ & $0.35 \pm 0.00^{c}$ & $2.15 \pm 0.01^{\mathrm{a}}$ \\
\hline$p$-value & $<0.001$ & $<0.001$ & $<0.001$ \\
\hline
\end{tabular}

Different superscripts indicate statistical differences by the Tukey test $(\mathrm{p}<0.05)$.

C: concentration

$\mu$ max: maximum growth rate

td: cell doubling time

In vitro effect of organic salts and the probiotic bacterium $L$. plantarum on the inhibition of different pathogenic bacteria

In vitro inhibition of pathogenic bacteria by organic salts and probiotic bacterium was significantly higher in all results when the probiotic was present $(\mathrm{p}<0.05)$. At $\mathrm{pH} 6.2$, sodium acetate and propionate with or without probiotic, in addition to butyrate tested separately, were the most effective organic salts against $V$. alginolyticus., Sodium propionate presented the highest inhibitory effect against A. hydrophila, E. coli and $P$. aeruginosa when cultured with $L$. plantarum. For $S$. agalactiae, sodium fumarate, but only in the presence of the probiotic, followed by sodium citrate, as much as combined with $L$. plantarum, as in isolation were effective inhibitors (Table 3). The sodium fumarate had no toxic effects on any bacteria tested in the absence of the probiotic. When tested separately, sodium succinate only exhibited toxicity against $E$. coli and $P$. aeruginosa, while sodium citrate only inhibited the growth of $V$. alginolyticus and $S$. agalactiae. On the other hand, sodium glutamate alone was only effective against $E$. coli, and similar to sodium citrate, it had no effect on $P$. aeruginosa, even in the presence of the probiotic. At both $\mathrm{pH}$ values, S. agalactiae was less sensitive to salts of organic acids compared with other pathogenic bacteria tested. 
Table 3. Minimum inhibitory concentration (MIC) (mM) of the different organic salts (pH 6.2) in the presence or absence of the probiotic bacterium L. plantarum against different pathogenic bacteria.

\begin{tabular}{|c|c|c|c|c|c|c|c|c|}
\hline \multicolumn{9}{|c|}{ Vibrio alginolyticus } \\
\hline & Fum & For & But & Ace & Pro & Glu & Cit & Suc \\
\hline N/P & $\mathrm{N}$ & $\begin{array}{l}36.76 \pm \\
0.00^{\mathrm{c}} \\
\end{array}$ & $\begin{array}{l}1.89 \pm \\
0.82^{\mathrm{b}} \\
\end{array}$ & $\begin{array}{l}0.24 \pm \\
0.00^{\mathrm{a}} \\
\end{array}$ & $\begin{array}{l}0.27 \pm \\
0.12^{\mathrm{a}} \\
\end{array}$ & $\mathrm{N}$ & $\begin{array}{l}1.61 \pm \\
0.70^{\mathrm{b}} \\
\end{array}$ & $\mathrm{N}$ \\
\hline $\mathrm{W} / \mathrm{P}$ & $\begin{array}{l}0.98 \pm \\
0.85^{\text {bcd }} \\
\end{array}$ & $\begin{array}{l}1.91 \pm \\
0.66^{\mathrm{d}}\end{array}$ & $\begin{array}{l}0.07 \pm \\
0.03^{\mathrm{a}}\end{array}$ & $\begin{array}{l}0.16 \pm \\
0.07^{\mathrm{a}} \\
\end{array}$ & $\begin{array}{l}0.17 \pm \\
0.06^{\mathrm{ab}}\end{array}$ & $\begin{array}{l}1.68 \pm \\
0.00^{d}\end{array}$ & $\begin{array}{l}1.01 \pm \\
0.35^{\mathrm{cd}} \\
\end{array}$ & $\begin{array}{l}4.46 \pm \\
0.01^{\mathrm{e}} \\
\end{array}$ \\
\hline \multicolumn{9}{|c|}{ Aeromonas hydrophila } \\
\hline & Fum & For & But & Ace & Pro & Glu & Cit & Suc \\
\hline $\mathrm{N} / \mathrm{P}$ & $\mathrm{N}$ & $\begin{array}{l}73.52 \pm \\
0.00^{d}\end{array}$ & $\begin{array}{l}22.71 \pm \\
0.00^{\mathrm{b}}\end{array}$ & $\begin{array}{l}30.48 \pm \\
0.00^{\mathrm{c}}\end{array}$ & $\begin{array}{l}6.51 \pm \\
0.00^{\mathrm{a}}\end{array}$ & $\mathrm{N}$ & $\mathrm{N}$ & $\mathrm{N}$ \\
\hline $\mathrm{W} / \mathrm{P}$ & $\begin{array}{l}7.81 \pm \\
0.00^{\mathrm{e}} \\
\end{array}$ & $\begin{array}{l}9.19 \pm \\
0.00^{\mathrm{f}}\end{array}$ & $\begin{array}{l}5.68 \pm \\
0.00^{\mathrm{b}}\end{array}$ & $\begin{array}{l}7.62 \pm \\
0.00^{\mathrm{d}}\end{array}$ & $\begin{array}{l}3.25 \pm \\
0.00^{\mathrm{a}}\end{array}$ & $\begin{array}{l}6.68 \pm \\
0.00^{c}\end{array}$ & $\begin{array}{l}9.69 \pm \\
0.00^{\mathrm{g}}\end{array}$ & $\begin{array}{l}35.71 \pm \\
0.00^{\mathrm{h}}\end{array}$ \\
\hline \multicolumn{9}{|c|}{ Escherichia coli } \\
\hline & Fum & For & But & Ace & Pro & Glu & Cit & Suc \\
\hline $\mathrm{N} / \mathrm{P}$ & $\mathrm{N}$ & $\begin{array}{l}36.76 \pm \\
0.00^{d}\end{array}$ & $\begin{array}{l}5.68 \pm \\
0.00^{\mathrm{b}}\end{array}$ & $\begin{array}{l}6.35 \pm \\
2.20^{\mathrm{b}} \\
\end{array}$ & $\begin{array}{l}3.25 \pm \\
0.00^{\mathrm{a}}\end{array}$ & $\begin{array}{l}26.72 \pm \\
0.00^{c}\end{array}$ & $\mathrm{~N}$ & $\begin{array}{l}35.71 \\
\pm 0.00^{c} \\
\end{array}$ \\
\hline $\mathrm{W} / \mathrm{P}$ & $\begin{array}{l}3.91 \pm \\
0.00^{c} \\
\end{array}$ & $\begin{array}{l}4.59 \pm \\
0.00^{\mathrm{c}} \\
\end{array}$ & $\begin{array}{l}2.84 \pm \\
0.00^{\mathrm{b}} \\
\end{array}$ & $\begin{array}{l}3.81 \pm \\
0.00^{c} \\
\end{array}$ & $\begin{array}{l}0.81 \pm \\
0.00^{\mathrm{a}}\end{array}$ & $\begin{array}{l}3.34 \pm \\
0.00^{c} \\
\end{array}$ & $\begin{array}{l}4.04 \pm \\
1.40^{\mathrm{c}} \\
\end{array}$ & $\begin{array}{l}8.93 \pm \\
0.00^{\mathrm{d}}\end{array}$ \\
\hline \multicolumn{9}{|c|}{ Pseudomonas aeruginosa } \\
\hline & Fum & For & But & Ace & Pro & Glu & Cit & Suc \\
\hline $\mathrm{N} / \mathrm{P}$ & $\mathrm{N}$ & $\begin{array}{l}36.76 \pm \\
0.00^{\mathrm{e}}\end{array}$ & $\begin{array}{l}22.71 \pm \\
0.00^{c}\end{array}$ & $\begin{array}{l}15.24 \pm \\
0.00^{\mathrm{b}}\end{array}$ & $\begin{array}{l}6.51 \pm \\
0.00^{\mathrm{a}}\end{array}$ & $\mathrm{N}$ & $\mathrm{N}$ & $\begin{array}{l}35.71 \pm \\
0.00^{\mathrm{d}}\end{array}$ \\
\hline $\mathrm{W} / \mathrm{P}$ & $\begin{array}{l}7.81 \pm \\
0.00^{\mathrm{d}} \\
\end{array}$ & $\begin{array}{l}9.19 \pm \\
0.00^{\mathrm{e}} \\
\end{array}$ & $\begin{array}{l}5.68 \pm \\
0.00^{\mathrm{b}} \\
\end{array}$ & $\begin{array}{l}7.62 \pm \\
0.00^{\mathrm{c}} \\
\end{array}$ & $\begin{array}{l}3.25 \pm \\
0.00^{\mathrm{a}} \\
\end{array}$ & $\mathrm{N}$ & $\mathrm{N}$ & $\begin{array}{l}17.86 \pm \\
0.00^{\text {f }} \\
\end{array}$ \\
\hline \multicolumn{9}{|c|}{ Streptococcus agalactiae } \\
\hline & Fum & For & But & Ace & Pro & Glu & Cit & Suc \\
\hline N/P & $\mathrm{N}$ & $\mathrm{N}$ & $\begin{array}{l}22.71 \pm \\
0.00^{\mathrm{b}}\end{array}$ & $\mathrm{N}$ & $\begin{array}{l}52.05 \pm \\
0.00^{c} \\
\end{array}$ & $\mathrm{~N}$ & $\begin{array}{l}9.69 \pm \\
0.00^{\mathrm{a}} \\
\end{array}$ & $\mathrm{N}$ \\
\hline $\mathrm{W} / \mathrm{P}$ & $\begin{array}{l}7.82 \pm \\
0.00^{\mathrm{a}} \\
\end{array}$ & $\begin{array}{l}18.38 \pm \\
0.00^{\mathrm{e}} \\
\end{array}$ & $\begin{array}{l}11.36 \pm \\
0.00^{c} \\
\end{array}$ & $\begin{array}{l}30.48 \pm \\
0.00^{\mathrm{g}} \\
\end{array}$ & $\begin{array}{l}26.02 \pm \\
0.00^{f}\end{array}$ & $\begin{array}{l}13.36 \pm \\
0.00^{\mathrm{d}}\end{array}$ & $\begin{array}{l}9.69 \pm \\
0.00^{\mathrm{b}}\end{array}$ & $\begin{array}{l}35.71 \pm \\
0.00^{\mathrm{h}} \\
\end{array}$ \\
\hline
\end{tabular}

Different superscripts indicate statistical differences by the Tukey test $(\mathrm{p}<0.05)$. N/P: without probiotic. W/P: with probiotic. N: No inhibition. Fum- fumarate, For-formiate, But-butyrate, Ace-acetate, Pro-propionate, Glu-glutamate, Cit-citrate, Sucsuccinate.

Statistical analysis revealed significant differences between the tested $\mathrm{pH}$ values $(\mathrm{p}<0.05)$, with higher inhibitory power at the lower $\mathrm{pH}(6.2)$. At the highest $\mathrm{pH}$ value (7.1), some of the organic salts exhibited reduced toxicity against the pathogenic bacteria, and in some cases, they completely lost their inhibitory effect (Table 4). For example, sodium glutamate, when tested separately, lost its inhibitory power against $E$. coli, as well as citrate and propionate against $S$. agalactiae and succinate against $E$. coli, P. aeruginosa and S. agalactiae. However, the same salts that showed the best inhibitory effects against pathogenic bacteria at $\mathrm{pH} 6.2$ were also those that showed the best inhibitory effects at $\mathrm{pH}$ 7.1. 
Table 4. Minimum inhibitory concentration (MIC) $(\mathrm{mM})$ of the different organic salts (pH 7.1) in the presence or absence of the probiotic bacterium L. plantarum against different pathogenic bacteria.

Vibrio alginolyticus

\begin{tabular}{lllllllll}
\hline & Fum & For & But & Ace & Pro & Glu & Cit & Suc \\
\hline \multirow{2}{*}{$\mathrm{N} / \mathrm{P}$} & $\mathrm{N}$ & $73.52 \pm$ & $2.37 \pm$ & $0.40 \pm$ & $0.34 \pm$ & \multirow{2}{*}{$\mathrm{N}$} & $2.02 \pm$ & \multirow{2}{*}{$\mathrm{N}$} \\
& & $0.00^{\mathrm{c}}$ & $0.82^{\mathrm{b}}$ & $0.14^{\mathrm{a}}$ & $0.12^{\mathrm{a}}$ & & $0.70^{\mathrm{b}}$ & \\
\hline \multirow{2}{*}{$\mathrm{W} / \mathrm{P}$} & $0.16 \pm$ & $2.30 \pm$ & $0.53 \pm$ & $0.24 \pm$ & $0.68 \pm$ & $2.78 \pm$ & $2.02 \pm$ & $4.46 \pm$ \\
& $0.07^{\mathrm{a}}$ & $0.00^{\mathrm{b}}$ & $0.31^{\mathrm{a}}$ & $0.00^{\mathrm{a}}$ & $0.23^{\mathrm{a}}$ & $0.96^{\mathrm{b}}$ & $0.70^{\mathrm{b}}$ & $0.00^{\mathrm{c}}$ \\
\hline
\end{tabular}

Aeromonas hydrophila

\begin{tabular}{lllllllll}
\hline & Fum & For & But & Ace & Pro & Glu & Cit & Suc \\
\hline \multirow{2}{*}{$\mathrm{N} / \mathrm{P}$} & $\mathrm{N}$ & $73.52 \pm$ & $45.42 \pm$ & $60.95 \pm$ & $6.51 \pm$ & \multirow{2}{*}{$\mathrm{N}$} & $\mathrm{N}$ & $\mathrm{N}$ \\
& $0.00^{\mathrm{d}}$ & $0.00^{\mathrm{b}}$ & $0.00^{\mathrm{c}}$ & $0.00^{\mathrm{a}}$ & & & \multirow{2}{*}{\begin{tabular}{l}
$\mathrm{N}$ \\
\multirow{2}{*}{$\mathrm{W} / \mathrm{P}$}
\end{tabular}} \\
& $7.81 \pm$ & $9.19 \pm$ & $5.68 \pm$ & $7.62 \pm$ & $3.25 \pm$ & $6.68 \pm$ & $9.69 \pm$ & $35.71 \pm$ \\
& $0.00^{\mathrm{d}}$ & $0.00^{\mathrm{e}}$ & $0.00^{\mathrm{b}}$ & $0.00^{\mathrm{d}}$ & $0.00^{\mathrm{a}}$ & $0.00^{\mathrm{c}}$ & $0.00^{\mathrm{f}}$ & $0.00^{\mathrm{g}}$ \\
\hline
\end{tabular}

Escherichia coli

\begin{tabular}{lllllllll}
\hline & Fum & For & But & Ace & Pro & Glu & Cit & Suc \\
\hline \multirow{2}{*}{$\mathrm{N} / \mathrm{P}$} & $\mathrm{N}$ & $36.76 \pm$ & $11.36 \pm$ & $15.23 \pm$ & $3.25 \pm$ & $\mathrm{N}$ & $\mathrm{N}$ & $\mathrm{N}$ \\
& $0.00^{\mathrm{d}}$ & $0.00^{\mathrm{bc}}$ & $0.00^{\mathrm{c}}$ & $0.00^{\mathrm{a}}$ & & & \multirow{2}{*}{$\mathrm{N}$} \\
\multirow{2}{*}{$\mathrm{W} / \mathrm{P}$} & $3.91 \pm$ & $4.59 \pm$ & $2.84 \pm$ & $3.81 \pm$ & $1.08 \pm$ & $3.34 \pm$ & $3.23 \pm$ & $8.93 \pm$ \\
& $0.00^{\mathrm{c}}$ & $0.00^{\mathrm{d}}$ & $0.00^{\mathrm{b}}$ & $0.00^{\mathrm{bc}}$ & $0.47^{\mathrm{a}}$ & $0.00^{\mathrm{b}}$ & $1.40^{\mathrm{bc}}$ & $0.00^{\mathrm{e}}$ \\
\hline
\end{tabular}

Pseudomonas aeruginosa

\begin{tabular}{lllllllll}
\hline & Fum & For & But & Ace & Pro & Glu & Cit & Suc \\
\hline \multirow{2}{*}{$\mathrm{N} / \mathrm{P}$} & $\mathrm{N}$ & $73.52 \pm$ & $22.71 \pm$ & $30.48 \pm$ & $6.51 \pm$ & \multirow{2}{*}{$\mathrm{N}$} & \multirow{2}{*}{$\mathrm{N}$} & $\mathrm{N}$ \\
& $0.00^{\mathrm{d}}$ & $0.00^{\mathrm{b}}$ & $0.00^{\mathrm{c}}$ & $0.00^{\mathrm{a}}$ & & & \multirow{2}{*}{$\mathrm{N}$} & \multicolumn{2}{c}{$17.86 \pm$} \\
$\mathrm{W} / \mathrm{P}$ & $7.81 \pm$ & $9.19 \pm$ & $5.68 \pm$ & $7.62 \pm$ & $3.25 \pm$ & \multirow{2}{*}{$\mathrm{N}$} & $\mathrm{N}$ & \\
& $0.00^{\mathrm{d}}$ & $0.00^{\mathrm{e}}$ & $0.00^{\mathrm{b}}$ & $0.00^{\mathrm{c}}$ & $0.00^{\mathrm{a}}$ & $\mathrm{N}$ \\
\hline
\end{tabular}

Streptococcus agalactiae

\begin{tabular}{lllllllll}
\hline & Fum & For & But & Ace & Pro & Glu & Cit & Suc \\
\hline $\mathrm{N} / \mathrm{P}$ & $\mathrm{N}$ & $\mathrm{N}$ & $\begin{array}{l}45.42 \pm \\
0.00\end{array}$ & $\mathrm{~N}$ & $\mathrm{~N}$ & $\mathrm{~N}$ & $\mathrm{~N}$ & $\mathrm{~N}$ \\
\hline $\mathrm{W} / \mathrm{P}$ & $7.82 \pm$ & $18.38 \pm$ & $11.36 \pm$ & $30.48 \pm$ & $26.02 \pm$ & $13.36 \pm$ & $\mathrm{N}$ & $\mathrm{N}$ \\
\hline
\end{tabular}

Different superscripts indicate statistical differences by the Tukey test (p<0.05). N/P: without probiotic. W/P: with probiotic. N: No inhibition. Fum- fumarate, For-formiate, But-butyrate, Ace-acetate, Pro-propionate, Glu-glutamate, Cit-citrate, Suc-succinate. P-v: p-value.

\section{DISCUSSION}

In vitro effect of organic salts on the growth of the probiotic bacterium $L$. plantarum

The inhibitory effect of citrate and sodium formate against L. plantarum is notable and can be explained by a key mechanism of action of organic acids whereby the bacterial cell wall in its non-ionized form is penetrated, consequently changing intracellular $\mathrm{pH}{ }^{11,19}$. This mechanism is activated in sodium citrate which, unlike other organic salts tested, has three carboxylic groups that increase the possibility of non-dissociation of this salt, thus retaining its toxic form ${ }^{20}$. Additionally, since it is a 
tricarboxylic acid, its dissociation constant has three pK values, 3.15, 4.76, and 6.39, meaning that at $\mathrm{pH} 3.15,4.76$ and 6.39, each carboxylic group is $50 \%$ dissociated and $50 \%$ undissociated ${ }^{19}$. Thus, at the two tested $\mathrm{pH}$ values, 6.2 and 7.1 , sodium citrate would theoretically have a carboxylic group in its mostly undissociated, or toxic form, while the other two groups are mostly dissociated, but with molecules not dissociated in smaller concentration. These undissociated molecules with molecules of the first undissociated group may help to increase the toxic effect. Therefore, sodium citrate is not the best salt to use in combination with $L$. plantarum.

On the other hand, sodium formate has only one carboxylic group with $\mathrm{pK}$ value= 3.77 , indicating that at both $\mathrm{pHs}$ it would be fully dissociated and therefore, in its nontoxic form. However, lactic acid bacteria are characterized by their production of different organic acids due to a decrease of the $\mathrm{pH}$ in the environment. Therefore, during the growth of the probiotic, the medium could have undergone changes in its $\mathrm{pH}$ such as influencing in the increase of the formate and citrate undissociated forms, increasing their toxicity ${ }^{20}$.

Dicarboxylic salts, such as glutamate $(\mathrm{pK}=2.10,9.47)$, fumarate $(\mathrm{pK}=3.03,4.5)$ and succinate $(\mathrm{pK}=4.2,5.6)$, stimulated the growth of the probiotic. In the two $\mathrm{pH}$ values tested, these salts are predominantly dissociated resulting in a lower inhibitory effect; but sodium glutamate has a carboxylic group that could be toxic for the cell. Despite of that, sodium glutamate has stimulated the growth of L. plantarum, possibly owing to protein stabilization by reactions between the amino group of the glutamate and the carboxyl groups of proteins of the microorganism ${ }^{21}$. Also, sodium glutamate is widely used as cryopreservative agent of lactic acid bacteria ${ }^{22}$. Additionally, the amino group of glutamate can serve as a nitrogen source and, at the same time, a precursor of glutamine, which can assist in protein synthesis, increasing probiotic viability ${ }^{23}$. On the other hand, it is also possible that both sodium succinate and fumarate could modulate the L. plantarum electron transport chain and thus serve as a metabolic source of energy ${ }^{24}$.

According to these results, sodium glutamate, succinate and fumarate are ideal for use in combination with $L$. plantarum.

\section{In vitro effect of organic salts and the probiotic bacterium $L$. plantarum on the inhibition of different pathogenic bacteria}

All organic salts tested showed better inhibition results against pathogenic bacteria in the presence of L. plantarum. Some organic salts have formed part of the nutritional requirements of lactic acid bacteria ${ }^{19}$, resulting in an increase in their concentration functioning as energy sources, thus improving the inhibitory effect obtained with such organic salts. Some authors suggest that the use of organic acids, such as propionic acid when combined with inoculation with lactic acid bacteria, can be beneficial to the bacterial inoculum itself, improving fermentation processes ${ }^{25}$. Moreover, the decrease in $\mathrm{pH}$ of lactic acid bacteria increases the concentration of undissociated organic salts (toxic form), in turn increasing their bactericidal efficacy ${ }^{26}$.

At $\mathrm{pH}$ 6.2, the results suggest that monocarboxylic acid salts, such as propionate, butyrate, and acetate, showed the best inhibitory effects against gram-negative bacteria. With pK values above 4.7, these salts would be undissociated in a higher concentration compared with formate (monocarboxylic acid) which, by its $\mathrm{pK}$ at 3.77 , would have a less toxic effect.

Dicarboxylic organic acid salts were not as efficient as the monocarboxylic acids, suggesting that these organic acid salts have acted as a source of energy by pathogenic bacteria since, in most cases, no inhibitory effect was observed in the absence of the probiotic.

As a tricarboxylic acid salt, sodium citrate exerts toxic effect against pathogenic bacteria at least with two of its acid carboxylic groups. However, this salt did not 
present the best inhibitory effects, and against some bacteria, it had no effect at all. Therefore, these bacteria could be using citrate as a carbon source through the tricarboxylic acid cycle, thus nullifying its inhibitory effect. However, in the case of $S$. agalactiae, the citrate did present inhibitory effect, suggesting that this salt is exercising its toxic effect, since like, $S$. agalactiae is unable to use citrate as energy source because lacks of a functional Krebs cycle and uses other metabolic routes of fermentation ${ }^{27}$.

The results of this study showed a higher in vitro inhibitory effect at $\mathrm{pH} 6.2$ than at $\mathrm{pH}$ 7.1. Similar results were obtained by Silva et al. ${ }^{14}$, who obtained a greater inhibition of Vibrio spp. in the presence of organic salts at low $\mathrm{pH}$ values. Environmental $\mathrm{pH}$ variations are important because they affect membrane permeability to acids as a result of the change in the ratio of dissociated to undissociated molecules ${ }^{26}$. At $\mathrm{pH} 7.1$, the salts had a less inhibitory effect on the bacteria which could be explained by the increase in medium $\mathrm{pH}$ which, in turn, increases the prevalence of the dissociated form (nontoxic) of acids, thereby preventing the molecule from penetrating the cell membrane, thus reducing toxicity 19.

Furthermore, $\mathrm{pH}$ values between 4.5 and 6.2 promote the growth of lactic acid bacteria belonging to the genus Lactobacillus ${ }^{28}$, whereas most of the tested pathogenic bacteria grow better at $\mathrm{pH}$ values above $729,30,31,32$.

In addition to decreasing intracellular $\mathrm{pH}$, organic acids can also form chelating complexes with minerals, making nutrients unavailable and limiting the growth of other microorganisms ${ }^{13}, 33$. Bacteria grow more slowly in absence of essential minerals such as iron. In this sense, the presence of microorganisms or substances that produce chelating complex compounds can inhibit their growth ${ }^{34,35}$.

Apart from competing for nutrients, lactic acid bacteria produce inhibitory compounds, such as hydrogen peroxide, bacteriocins and organic acids ${ }^{9}$. Experiments confirm the potential of different species of probiotic Lactobacillus to inhibit specific pathogens through the production of such inhibitory compounds ${ }^{36,37}$, which could complement the action of organic salts used in this experiment.

In general, $S$. agalactiae was less sensitive to the effects of organic salts, possibly because it is a gram-positive bacterium characterized by a thick layer of peptidoglycan in its cell wall, thus increasing resistance ${ }^{27}$.

\section{CONCLUSION}

At both $\mathrm{pH}$ values, L. plantarum growth was inhibited by sodium citrate and formate, increased by sodium succinate, fumarate, and glutamate, and not affected at all by propionate, butyrate, or acetate.

On the other hand, at both $\mathrm{pH}$ values, butyrate, acetate, and propionate led to higher inhibition against $V$. alginolyticus, propionate alone led to higher inhibition against $A$. hydrophila, E. coli, $P$. aeruginosa, and fumarate alone led to higher inhibition against $S$. agalactiae. The evaluated organic salts presented a stronger across-the-board inhibitory effect in the presence of the probiotic bacterium and also presented a lower inhibition effect against the gram-positive bacterium tested.

Even though the sodium succinate, fumarate and glutamate increased the concentration of $L$. plantarum they have not improved their inhibitory power against most of the pathogens. So, we suggest that the salts sodium butyrate and propionate could to be used in combination with the probiotic against different pathogenic bacteria. 


\section{ACKNOWLEDGMENTS}

The authors of this study acknowledge the financial support of the Conselho Nacional de Desenvolvimento Cientifico e Tecnológico (CNPq/475906/2012-8) and Coordenação de Aperfeiçoamento de Pessoal de Nível Superior (CAPES PEC-PG). Felipe Vieira and Walter Seiffert revived productivity research fellowships from CNPq (protocol no. PQ 309868/2014-9 and 302792/2012-0 respectively).

The authors declare no conflict of interest

\section{REFERENCES}

1. FAO (2015) Fisheries Global Information System. <http://www.fao.org/fishery/figis/en>. Acesso em 11 de Junio 2015.

2. FAO (Food and Agriculture Organization of the United Nations). The State of World Fisheries and Aquaculture, Rome: SOFIA, 2012.

3. Lightner DV, Redman RM, Pantoja CR, Tang KF, Noble BL, Schofield P, et al. Historic emergence, impact and current status of shrimp pathogens in the Americas. J Invertebr Pathol. 2012;110 (2):174-83.

4. Tran L, Nunan L, Redman RM, Mohney LL, Pantoja CR, Fitzsimmons K, et al. Determination of the infectious nature of the agent of acute hepatopancreatic necrosis syndrome affecting penaeid shrimp. Dis Aquat Organ. 2013; 105(1):45-55.

5. Lafferty KD, Harvell CD, Conrad JM, Friedman CS, Kent ML, Kuris AM, et al. Infectious Diseases Affect Marine Fisheries and Aquaculture Economics. Ann Rev Mar Sci. 2015;7:471-96.

6. Alicia E. Toranzo, Beatriz Magariños, Jesús L. Romalde. A review of the main bacterial fish diseases in mariculture systems, Aquaculture, Volume 246, Issues 1-4, 18 May 2005, 37-61

7. Defoirdt T, Sorgeloos P, Bossier P. Alternatives to antibiotics for the control of bacterial disease in aquaculture. Curr Opin Microbiol. 2011; 14(3):251-8.

8. Graslund S, Holmstrom K, Wahlstrom A. A field survey of chemicals and biological products used in shrimp farming. Mar Pollut Bull. 2003; 46(1):81-90.

9. Gatesoupe FJ. Updating the importance of lactic acid bacteria in fish farming: natural occurrence and probiotic treatments. J Mol Microbiol Biotechnol. 2008; 14(1-3):107-14.

10. Castex M, Lemaire P, Wabete N, Chim L. Effect of probiotic Pediococcus acidilactici on antioxidant defences and oxidative stress of Litopenaeus stylirostris under Vibrio nigripulchritudo challenge. Fish Shellfish Immunol. 2010; 28(4):622-31.

11. Luckstadt $C$. The use of acidifiers in fish nutrition. CAB Reviews: perspectives in agriculture, veterinary science, nutrition and natural resources. 2008; 3:1-8.

12. Partanen KH, Mroz Z. Organic acids for performance enhancement in pig diets. Nutr Res Rev. 1999; 12(1):117-45.

13. Jones DL. Organic acids in the rhizosphere-a critical review. Plant and soil. 1998; 205(1):25-44.

14. Silva BC, Vieira FdN, Mouriño JLP, Ferreira GS, Seiffert WQ. Salts of organic acids selection by multiple characteristics for marine shrimp nutrition. Aquaculture. 2013; 384:104-10.

15. Franco LD, Fondevila M, Lobera MB, Castrillo C. Effect of combinations of organic acids in weaned pig diets on microbial species of digestive tract contents and their response on digestibility. J Anim Physiol Anim Nutr (Berl). 2005; 89(3-6):88-93.

16. Iba AM, Berchieri A, Jr. Studies on the use of a formic acid-propionic acid mixture (Bioadd) to control experimental Salmonella infection in broiler chickens. Avian Pathol. 1995;24(2):303-11.

17. Vieira FdN, Pedrotti FS, Buglione Neto CC, Mouriño JLP, Beltrame E, Martins ML, et al. Lactic-acid bacteria increase the survival of marine shrimp, Litopenaeus vannamei, after infection with Vibrio harveyi. Braz J Oceanogr. 2007; 55:251-5.

18. Zar JH. Biostatistical Analysis. 2 ed: Prentice Hall; 1984. 718 p. 
19. Defoirdt T, Boon N, Sorgeloos P, Verstraete W, Bossier P. Short-chain fatty acids and poly- $\beta$-hydroxyalkanoates:(New) Biocontrol agents for a sustainable animal production. Biotechnol. Adv. 2009; 27(6):680-5.

20. Cherrington CA, Hinton, M., Pearson, G.R. and Chopra, I. Short-chain organic acids at pH 5.0 kill Escherichia coli and Salmonella spp. without causing membrane perturbation. J Appl Microbiol. 1991; 70:161-5.

21. Carvalho AS, Silva J, Ho P, Teixeira P, Malcata FX, Gibbs P. Protective effect of sorbitol and monosodium glutamate during storage of freeze-dried lactic acid bacteria. Le Lait. 2003; 83(3):203-10.

22. Hubalek Z. Protectants used in the cryopreservation of microorganisms. Cryobiology. 2003; 46(3):205-29.

23. Newsholme, P., Procopio, J., Lima, M. M. R., Pithon-Curi, T. C. and Curi, R., Glutamine and glutamate - their central role in cell metabolism and function. Cell Biochem. Funct. $2003 ; 21: 1-9$.

24. Lehninger ALN, D.A.; Cox, M.M. Principles of biochemistry: New York: Worth Publishers; 2007.

25. Kung Jr L, Myers C, Neylon J, Taylor C, Lazartic J, Mills J, et al. The effects of buffered propionic acid-based additives alone or combined with microbial inoculation on the fermentation of high moisture corn and whole-crop barley. J. Dairy Sci. 2004; 87(5):13106.

26. Marschner H. Mineral Nutrition of Higher Plants. . 2nd ed. London: Academic Press; 1995.

27. Salminem S, Wright, A. Lactic acid bacteria. 2 ed. New York-Basel: Marcell Decker Inc.; 1998

28. Hammes WP, Hertel C. The genera Lactobacillus and Carnobacterium. The prokaryotes: Springer; 2006. p. 320-403.

29. Gale EF, Epps HMR. The effect of the $\mathrm{pH}$ of the medium during growth on the enzymic activities of bacteria (Escherichia coli and Micrococcus lysodeikticus) and the biological significance of the changes produced. Biochem J. 1942; 36(7-9):600-18.

30. Nakamura TT, H.; Unemoto. Effects of $\mathrm{pH}$ and monovalent cations on the potassium ion exit from the marine bacterium, Vibrio alginolyticus, and the manipulation of cellular cation contents. Biochim. Biophys. Acta, Rev. Biomembr. 1982; 692:389-96.

31. Thomas KL, Lloyd D, Boddy L. Effects of oxygen, $\mathrm{pH}$ and nitrate concentration on denitrification by Pseudomonas species. FEMS Microbiol Lett. 1994; 118(1-2):181-6.

32. Yang Q, Porter AJ, Zhang M, Harrington DJ, Black GW, Sutcliffe IC. The impact of pH and nutrient stress on the growth and survival of Streptococcus agalactiae. Antonie Van Leeuwenhoek. 2012; 102(2):277-87.

33. Cardoso E, Nogueira MA. A rizosfera e seus efeitos na comunidade microbiana e na nutrição de plantas. In: Silveira \& Freitas. Microbiota do solo e qualidade ambiental. São Paulo: Instituto Agronômico Campinas; 2007.

34. Patel M, Isaäcson M, Gouws E. Effect of iron and $\mathrm{pH}$ on the survival of Vibrio cholerae in water. Trans R Soc Trop Med Hyg1995; 89(2):175-7.

35. Whitaker WB, Parent MA, Naughton LM, Richards GP, Blumerman SL, Boyd EF. Modulation of responses of Vibrio parahaemolyticus $\mathrm{O} 3$ : $\mathrm{K} 6$ to $\mathrm{pH}$ and temperature stresses by growth at different salt concentrations. Appl Environ Microbiol. 2010; 76(14):4720-9.

36. Vázquez JA, González MP, Murado M. Effects of lactic acid bacteria cultures on pathogenic microbiota from fish. Aquaculture. 2005; 245(1):149-61.

37. Tejero-Sarinena S, Barlow J, Costabile A, Gibson GR, Rowland I. In vitro evaluation of the antimicrobial activity of a range of probiotics against pathogens: evidence for the effects of organic acids. Anaerobe. 2012; 18(5):530-8.

Received: November 21, 2016 Accepted: June 30, 2018 